\title{
Long-Range Planning Committee Steers Society's Expansion
}

Woody White*

Oak Ridge National Laboratory

The year 1985 is a very active year for the Society's Long-Range Planning Committee. This Committee is charged with the responsibility of giving careful consideration to the long-range goals and objectives of the Materials Research Society, and for suggesting ways and means to achieve these objectives. The last few years have been a time of very rapid growth in the membership and activities of the MRS. This growth shows no signs of leveling off, and consequently the work of the LongRange Planning Committee becomes even more crucial to the orderly evolution of MRS.

Some of the important issues facing MRS at this time concern the type of activities the Society will provide to the materials research community in the future, and the financial obligation these activities will entail.

For the first time, the committee is at tempting to project the size and activities of MRS several years into the future, so that we can have a realistic estimate of the permanent staff and Headquarters space necessary to provide the services. Under active study is the question of whether MRS should purchase a building to house MRS Headquarters. The present Headquarters was established in Pittsburgh only two years ago, but already the staff has been

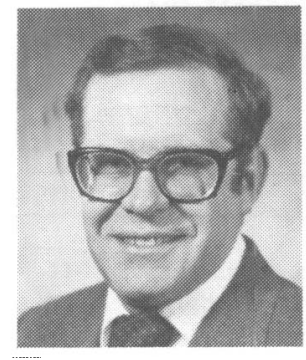

\section{Woody White}

expanded twice and the Headquarters has now completely outgrown the rental space it occupies. As part of this study, the Committee is considering ways in which MRS might finance the purchase of a Headquarters building, and methods are being explored to identify additional sources of revenue to support ongoing activities.

Additional activities of the Long-Range Planning Committee include: (1) identifying other topical areas to be included in future MRS meetings to provide broader topical coverage; (2) exploring ways to more actively involve university faculty with MRS; (3) contributing to the further development of MRS as a truly international organization by providing encouragement for MRSstyle activities in other geographical regions; and (4) contributing to a significant expansion of the MRS Awards Program.

MRS is undergoing rapid growth because the Society provides a necessary service to the materials research community. Through its meetings, short courses, MRS BULLETIN, conference proceedings, and the newly established Journal of Materials Research, the Society provides forums for the dissemination of information on interdisciplinary materials research. Many of these activities were begun following suggestions and guidance provided by the Long-Range Planning Committee. If the Society is to provide additional services to the community in the future, this Committee must anticipate several years in advance additional services and activities that will be required. The Committee attempts to do this by carefully considering the future needs of the materials research profession and then suggesting ways in which the Materials Research Society can satisfy those needs.

The Long-Range Planning Committee is chaired by Woody White, Immediate Past President of MRS. Committee members are Arden Bement, Bob Chang, Millie Dresselhaus, Ken Jackson, Elton Kaufmann, Harry Leamy, Clyde Northrup, Gordon Pike, Bob Rosenberg, Rustum Roy, Dick Schwoebel, Jan Skalny, and Fred Young.

"Woody White is chairperson of the Long-Range Planning Committee.

\section{Finance Committee Meets Challenge of Rapid Society Growth}

Donald E. Harrison *

Westinghouse Corporation

Many very recent developments in the evolution of the Materials Research Society have resulted in the expansion and acceleration of activity by Finance Committee. The Committee's purpose is twofold: to ensure the overall financial health of the Society through monitoring its income and expenditures and to recommend and investigate new sources of income and costsaving measures in support of Society activities.

Within the last two years MRS Headquarters has been established which now is comprised of seven full-time staff members; a computer system has been implemented to support membership records and general Society operations; and a new archival journal has been developed as a major membership benefit for the coming year, not to mention the more visible growth demonstrated in MRS' technical programming, short course program, proceedings publications, and MRS BULLETIN.

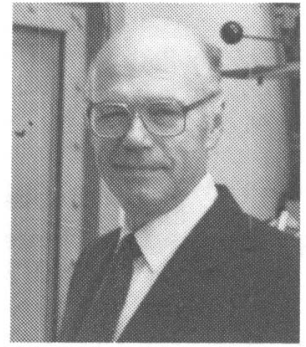

Don Harrison

The Finance Committee, responding to the need for sound financial planning and control of MRS resources in support of this growth, has been working on a number of projects in cooperation with Committee chairs and MRS Treasurer Clif Draper.

Under direction provided by the Finance Committee, the Headquarters staff has increased by $75 \%$ within the last two months, but to accommodate this change the overall operating budget has risen $23 \%$. The Committee has recently conducted a study on upgrading the accounting system at MRS Headquarters and investigated hardware and software options to accomplish this task. It was responsible for conducting an audit of 1984 finances, obtaining Council approval in April for 1985 budget recommendations, and is now beginning the yearly budget cycle again for 1986. The Committee is also investigating options for constructing or buying an MRS Headquarters building.

At the same time the MRS Publications Committee was examining the efficacy of a new archival journal. The Finance Committee was charged with providing a financial assessment of the impact that such a journal would have during its crucial start.. up period. To help ensure the viability of this major new publication the Committee is actively examining ways to allow various foundations and corporations to buttress other sources of support.

(continued on the next page) 